\title{
THE POSSIBILITY OF UTILIZATION OF SEWAGE SLUDGE AS A FILLER IN PRODUCTION OF THE LIGHTWEIGHT AGGREGATE CONCRETE
}

\author{
MOŻLIWOŚĆ ZAGOSPODAROWANIA OSADÓW ŚCIEKOWYCH \\ JAKO WYPEENIACZ W PRODUKCJI KERAMZYTOBETONU
}

\begin{abstract}
The article presents the laboratory investigations of the basic thermal and hygric parameters of standard lightweight aggregate-concrete and lightweight aggregate-concrete supplemented with municipal sewage sludge. Both types of concrete are based on light aggregates, commonly used in the Polish building market. In order to improve the hygric parameters of the material, such as water absorptivity, the admixture of water emulsion of reactive polisiloxanes was applied. Within the presented research, together with basic moisture parameters estimation, capillary rise process was monitored using Time Domain Reflectometry (TDR) modified sensors. Hygric parameters were supplemented with the estimation of thermal conductivity coefficient $\lambda$ determined using stationary method. The analysis of thermal and hygric properties of concrete confirmed the applicability of lightweight aggregate-concrete with sewage sludge supplementation for further production.
\end{abstract}

Keywords: hygric properties, capillary rise, thermal conductivity coefficient, aggregate-concrete, hydrophobisation

\section{Introduction}

Recently, the improvement in terms of modernizing the exploitation of domestic energy resources has gained increasing economic attention. This effort is aimed at minimizing the consumption of primary energy [1, 2]. The EU directive 2006/32/WE3 of $17^{\text {th }}$ May 2006 [3] obliged the Member States, including Poland, to reduce the amount of energy used by building residents over nine consecutive years, beginning with 01.01.2008. The energetic performance could be improved by energy saving technologies for building construction as well as applying renewable energy sources for powering buildings.

\footnotetext{
${ }^{1}$ Faculty of Environmental Engineering, Lublin University of Technology, ul. Nadbystrzycka 40B, 20-618 Lublin, Poland, email: g.lagod@pollub.pl

${ }^{2}$ Faculty of Civil Engineering and Architecture, Lublin University of Technology, ul. Nadbystrzycka 40, 20-618 Lublin, Poland, email: d.barnat-hunek@pollub.pl, m.franus@pollub.pl

${ }^{3}$ Faculty of Civil Engineering, Czech Technical University in Prague, Thákurova 7, 16629 Prague, Czech Republic, email: pavlikz@fsv.cvut.cz

*Corresponding author: z.suchorab@pollub.pl
} 
The data collected by the Polish Central Statistical Office for 1997-2007 [4] indicates that central heating corresponds to $31-71 \%$ of the final energy consumption in Polish households. This value is similar to the average final energy consumption for Europe, amounting to $50 \%$ [5]. The housing sector, with its high consumption of energy, is responsible for releasing substantial quantities of carbon dioxide into the atmosphere, corresponding to approximately $50 \%$ of total emissions. Literature contains numerous accounts pertaining to the impact of building technologies on the environment [6-9], usually involving the emission of carbon dioxide and fuel consumption.

The main factors that affect the energy consumption by buildings, their durability air quality and heat comfort are the physical and moisture properties of building materials [10-12]. In the case of non-insulated buildings, inadequate ventilation and thermal insulation of rooms results in the occurrence of condensation [13, 14]. This phenomenon is especially important for the partitions that remain in direct contact with the ground. Literature $[15,16]$ confirms that the capillary water transport has a significant impact on the heat flow, increasing the thermal conductivity of porous materials by 4-6-fold. High moisture content has a negative impact on the indoor air, resulting in the development of hazardous microorganisms as well as chemical and biological corrosion. Thus, the costs of exploitation may be increased. The development of mould and fungi in building barriers mainly depends of the moisture and temperature. As confirmed by laboratory experiments, the growth of mould is influenced by variable moisture and temperature conditions. The increased moisture induces changes in the indoor microclimate and reduces the thermal comfort. Consequently, infections, allergies, eye or skin irritation as well as respiratory system disorders may appear [17-21].

In line with the EU Directive 2006/32/WE3 [3], ecological and energy-saving building materials are manufactured in order to improve the energy effectiveness that characterizes buildings. Lightweight aggregate-concrete, given its heat and moisture parameters, constitutes a material which is currently applied for energy-saving civil engineering. The lightweight aggregate-concrete enables to reduce the weight of employed construction materials, in relation to the traditional concrete. The particle density of the majority of natural aggregates ranges from 2.4 to $2.8 \mathrm{~g} / \mathrm{cm}^{3}$ (usually $2.6 \mathrm{~g} / \mathrm{cm}^{3}$ ), whereas the values characterizing the lightweight aggregates are in the range from 0.8 to $2.0 \mathrm{~g} / \mathrm{cm}^{3}$ [22]

Reduced deadweight, resulting from a decreased size of the structural and foundation elements could also lower the costs of construction.

The results obtained from scientific research indicate that lightweight concrete may be obtained by modifying lightweight aggregates by means of municipal sewage sludge $[22,23]$ and applied in the sector of building industry to rise halls, factories, magazines and other types of buildings.

Over the last decades, the re-use of industrial wastes as well as the application of recycled materials has become an increasingly popular solution, worldwide. Certain types of wastes can be converted into ceramic products through heat treatment [24-26].

The quantity of produced sewage sludge is on a rapid increase, resulting from the growing number of sewage treatment plants as well as improving treatment process efficiency involving the removal of biogens and carbon compounds]. Sewage sludge must be processed in an appropriate way, because it frequently poses a threat to the natural environment resulting, for instance, from high heavy metal content [27].

Deposition of sewage sludge in landfills and its application in agriculture were limited through the regulations issued by the European Union [28-31]. Reuse of sewage sludge in 
the production of energy-saving lightweight aggregate-concrete blocks as well as ceramic materials $[26,32]$ constitutes one of the prospective solutions. However, the structure of light aggregates results in high moisture absorptivity of sewage sludge, posing problems with the composition of lightweight aggregate-concrete, both mixtures and ready-products. The heat flow process is affected by the raised thermal conductivity of materials. The essential features for lightweight concrete production include the type and distribution of pore networks, and their connection with the aggregate surface. When the cement mortar has an inadequate viscosity, the aggregates may flow out as a result of the different volumetric densities characterizing the lightweight aggregate and the mortar. There are several solutions to the subtraction of water needed for the hydration of lightweight aggregate. Initial wetting carried out to prevent autogenic contraction of the aggregates is one of such methods [33]. An alternative technique involves covering the aggregates with ceramic shell or cement grout, thus increasing the density of aggregate particles and lowering the water absorptivity of the aggregates [34]. Impregnation of aggregates, resulting in the closure of air gaps, protecting from water penetration with constant adherence of particles to the cement constitutes a novel technology. Although the capillary water absorption is reduced through hydrophobisation, the pores or capillaries remain unsealed, allowing for free permeability of vapors [35]. Siloxanes (water-soluble organic silica compounds), when used in 1-2\% in relation to the mass of cement, may be employed for hydrophobisation [36]. Conducting hydrophobisation in the course of lightweight block production solves the problem of excessive moisture occurring during the building exploitation. Moreover, it largely prevents the transport of saline solutions into masonry, protecting against the erosion of material ensuing from repeated freezing and thawing cycles in winter, as well as the crystallization of dissolved salt. It should be noted that salt-free materials exhibit lower moisture than the ones containing salt. In turn, the heat flow process is greatly affected by excessive moisture, increasing the thermal conductivity of materials and contributing to energy losses [37].

The obtained results may be taken into consideration while preparing the guidelines pertaining to the practical use of hydrophobized lightweight aggregate-concrete with sewage sludge. The usefulness of lightweight aggregates supplemented with sewage sludge for the production of ecological and energy-saving blocks may be proven by conducting the analysis of physical, mechanical, as well as heat-moisture properties of the concrete. The application of newly-designed energy-saving materials for building constriction constitutes a step towards achieving lower final energy consumption.

\section{Materials and methods}

\section{Materials used for manufacturing of the concrete}

Two kinds of lightweight aggregate-concrete samples were prepared under laboratory conditions. Both types of material differed in the aggregates type. The aggregates from Light Aggregates Company "Keramzyt" in Mszczonow, Poland were used for the first (1) type of concrete. For the second (2) type of concrete, the aggregates were hand-made of clay from Light Aggregates Company "Keramzyt" in Mszczonow, Poland, supplemented with $10 \%$ addition of sewage sludge from municipal wastewater treatment plant "Hajdow" in Lublin, Poland. The following parameters characterized sewage sludge applied for the mixture: moisture content $-80.43 \%$, alkalinity $-750 \mathrm{mg} \mathrm{CaCO} / \mathrm{dm}^{3}$, total organic matter $65 \%$, pH - 7.57, VFAs - $91 \mathrm{mg} / \mathrm{dm}^{3}$, COD - $134.531 \mathrm{mg} \mathrm{O}_{2} / \mathrm{dm}^{3}$, dry mass $-19.17 \%$, loss 
on ignition $-60.13 \%$, the residue on ignition $-39.03 \%$, density $-0.786 \mathrm{~g} / \mathrm{cm}^{3}, \mathrm{Zn}(\mathrm{II})$ 210.03 ppm, $\mathrm{Cu}(\mathrm{II})$ - 83.09 ppm, Cr(II) - 13.06 ppm, Ni(II) - 6.12 ppm, $\mathrm{Pb}(\mathrm{II})$ - 7.86 ppm, Cd(II) - $3.48 \mathrm{ppm}, \mathrm{P}-123.5 \mathrm{mg} / \mathrm{dm}^{3}$.

Sewage sludge samples were taken from the storage area, and dried to a constant weight at $110^{\circ} \mathrm{C}$. Dry sludge was ground and then supplemented with clay in the amount of $10 \%$ by weight. Homogenization process involved mixing the components with the corresponding portion of water to achieve the plastic consistency. Afterwards, the $16 \mathrm{~mm}$ spheres of coarse fraction were subjected to dying to achieve the air-dry state and placed in a laboratory oven for $2 \mathrm{~h}$ at $110{ }^{\circ} \mathrm{C}$. Subsequently, the samples were put into a chamber furnace and fired for 30 minutes at the temperature of $1150{ }^{\circ} \mathrm{C}$.

Basic characteristics of the applied aggregates for both types of concretes are presented in the Table 1.

Table 1

Basic characteristics of lightweight aggregates applied for research

\begin{tabular}{|c|c|c|c|c|}
\hline \multirow{2}{*}{ Type of aggregates } & Density & Apparent density & Absorptivity & Porosity \\
\cline { 2 - 5 } & {$\left[\mathbf{k g} / \mathbf{m}^{\mathbf{3}}\right]$} & {$\left[\mathrm{kg} / \mathbf{m}^{\mathbf{3}}\right]$} & {$[\%]$} & {$[\%]$} \\
\hline 1 & 2478 & 1033 & 20.4 & 29.5 \\
\hline 2 & 2624 & 811 & 17.1 & 40.2 \\
\hline
\end{tabular}

\section{Preparation of the samples}

In order to manufacture the samples of lightweight aggregate-concrete, the following components were applied: cement CEM I 32.5R, light aggregates described in the previous sub-section (8-16 mm), quartzite sand (0-2 mm) from Suwalki (SKSM), Poland, and water from the municipal water supply system in Lublin, Poland. Water solvable organic silica compounds, polysiloxanes, in an amount of $2 \%$, compared to the cement mass, were applied as a hydrophobic material. The concrete samples were manufactured according to the Polish [38, 39] standards. The design assumptions involve plastic consistency $D_{\max }=16 \mathrm{~mm}$. Table 2 presents the composition of the analyzed light concretes per $1 \mathrm{~m}^{3}$.

Lightweight concretes composition (per $\left.1 \mathrm{~m}^{3}\right)[\mathrm{kg}]$

Table 2

\begin{tabular}{|c|c|c|c|c|c|}
\hline Type of concrete & Cement & Sand & $\begin{array}{c}\text { Aggregates } \\
\text { (G8-G16) }\end{array}$ & Water & $\begin{array}{c}\text { Hydrophobic } \\
\text { substance }\end{array}$ \\
\hline 1 & 282 & 468 & 543 & 222 & 5.55 \\
\hline 2 & 273 & 451 & 502 & 201 & 5.43 \\
\hline
\end{tabular}

Two sets of samples were prepared. The first set of the samples with the following dimensions: $150 \times 150 \times 150 \mathrm{~mm}$, was prepared for standard examinations and water uptake monitoring. The samples were formed directly after concrete compounds had been mixed. They were condensed in two layers by vibrations until cement grout appeared on the surface of the mortar. The samples were disassembled after 24 hours of maturation and placed in water basin according to the Polish Standard [38], until full average strength was reached (age of the examined samples - 28 days).

Another set of samples was prepared for thermal conductivity determination. For that purpose, 3 plates of each concrete type were prepared. Each plate had the following dimensions: $300 \times 300 \times 50 \mathrm{~mm}$. 
The following measurements were conducted within the experiment:

- $\quad$ Real density (in line with PN-EN 1936:2010 [39] standard).

- $\quad$ Apparent density (PN-EN 1936:2010 [39] standard).

- Absorptivity.

- Porosity.

- Capillary uptake experiment, monitored using the TDR (Time Domain Reflectometry) equipment [40, 41].

- Thermal Conductivity Coefficient, using stationary method.

- Microstructure of aggregate-concrete using SEM (Scanning Electron Microscope).

TDR technology applied for moisture evaluation of hard building materials required modification of the traditional reflectometric sensors, which in the standard version are small and not stiff enough to be inserted into the structure of aggregate-concrete. For that purpose, the TDR sensors that could be used in this particular experiment were intentionally developed and manufactured. A non-invasive construction of TDR sensor was developed. It was made of PVC plate with the dielectric permittivity value of about 3.3 [42]. The $10 \times 10 \mathrm{~mm}$ angle bars $(15 \mathrm{~cm}$ long) were used as the waveguides. Both angle bars were connected with concentric cable, providing communication with the TDR multimeter. The spacing between the rods was about $30 \mathrm{~mm}$. Modified sensor construction is presented in Figure 1.

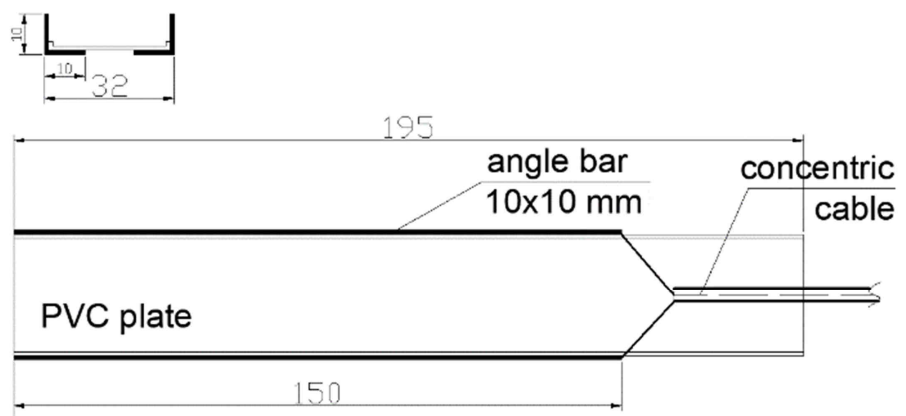

Fig. 1. Schematic view of the TDR sensor developed for the experiment

The probes were calibrated for moisture. Before calibration, lightweight aggregate concrete samples were dried and sequentially moisturized to achieve saturation status. Reflectometric data were acquired together with gravimetric readouts (effective dielectric permittivity $\left.\varepsilon_{e f f}\right)$. Calibration curve was achieved with the obtained data, which was subsequently used to build the regression model according to the formula (1):

$$
\theta=\beta_{0}+\beta_{1} \cdot \overline{\varepsilon_{e f f}}+\beta_{2} \cdot{\overline{\varepsilon_{e f f}}}^{2} \quad\left[\mathrm{~cm}^{3} / \mathrm{cm}^{3}\right]
$$

where: $\theta$ - volumetric water content estimated as polynomial model; $\overline{\varepsilon_{e f f}}$ - average value of the effective dielectric permittivity in reflectometric readouts [-].

The probes were installed on the examined sample in the following levels: $5 \mathrm{~cm}$ above water table and $10 \mathrm{~cm}$ above water table (Fig. 2). The duration of the whole experiment was set to 350 hours, until no significant water increase was observed. Capillary suction 
experiment was conducted on both samples (i) aggregate-concrete with aggregates from Mszczonow and (ii) aggregate concrete with aggregates from sewage sludge.

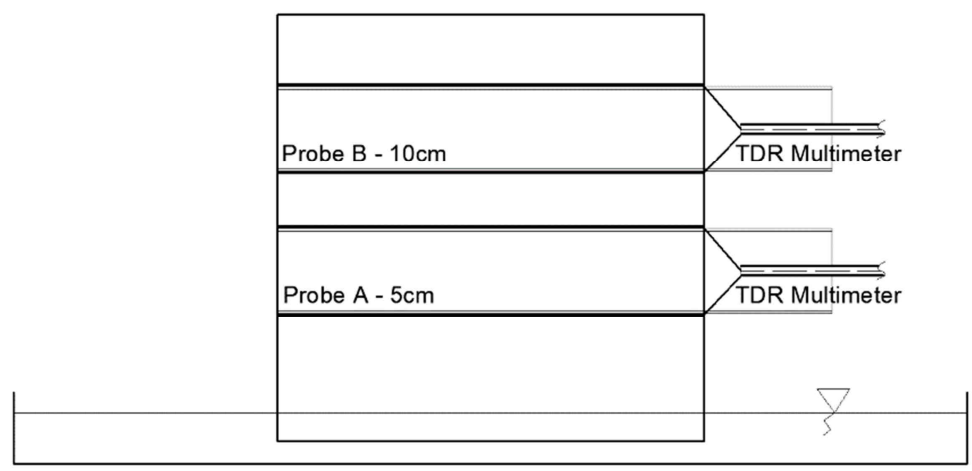

Fig. 2. Capillary uptake process determination - schematic view of measuring setup

In order to measure the thermal conductivity coefficient, Laser Comp FOX 314 plate apparatus, and the set of 3 plates was used for examination. Thermal conductivity coefficient of the material was determined by setting the temperature gradient of $20{ }^{\circ} \mathrm{C}$ between heating and cooling plate. For that aim, the following temperatures were applied: $20{ }^{\circ} \mathrm{C}$ for heating plate and $0{ }^{\circ} \mathrm{C}$ for the cooling plate. Average temperature was equal $10{ }^{\circ} \mathrm{C}$.

Morphological forms and chemical composition of both type of concretes were additionally examined using Scanning Electron Microscope FEI Quanta 250 FEG.

\section{Results}

The basic data pertaining to the materials achieved within the experiment are presented in Table 3.

Table 3

Physical properties of the examined aggregate-concretes

\begin{tabular}{|c|c|c|c|c|}
\hline \multirow{2}{*}{ Type of concrete } & Real density & $\begin{array}{c}\text { Apparent } \\
\text { density }\end{array}$ & Absorptivity & Porosity \\
\cline { 2 - 5 } & {$\left[\mathbf{g} / \mathbf{c m}^{\mathbf{3}}\right]$} & {$\left[\mathbf{g} / \mathbf{c m}^{3}\right]$} & {$[\%]$} & {$[\%]$} \\
\hline $\begin{array}{c}\text { Without sludge } \\
\text { additives }\end{array}$ & 2381 & 1446 & 7 & 39.5 \\
\hline $\begin{array}{c}\text { With aggregates from } \\
\text { sewage sludge }\end{array}$ & 2453 & 1347 & 4 & 45.6 \\
\hline
\end{tabular}

Dynamics of moisture increase by both types of concrete obtained using TDR readouts are presented below. Figure 3 shows the calibration curve and estimated within calibration experiment. Table 4 presents the regression formula and its basic statistical parameters. 


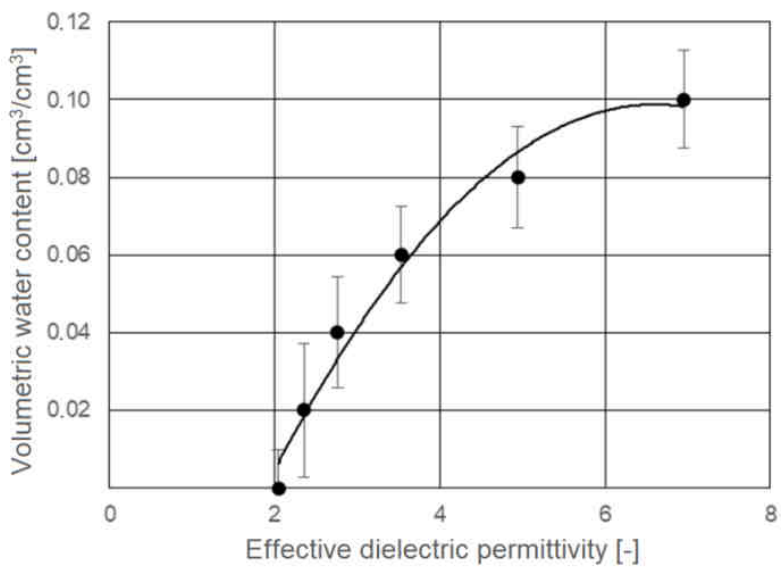

Fig. 3. Dependence between effective dielectric permittivity $\varepsilon_{\text {eff }}$ measured by TDR probe and volumetric water content $\theta$ of lightweight aggregate-concrete

a)

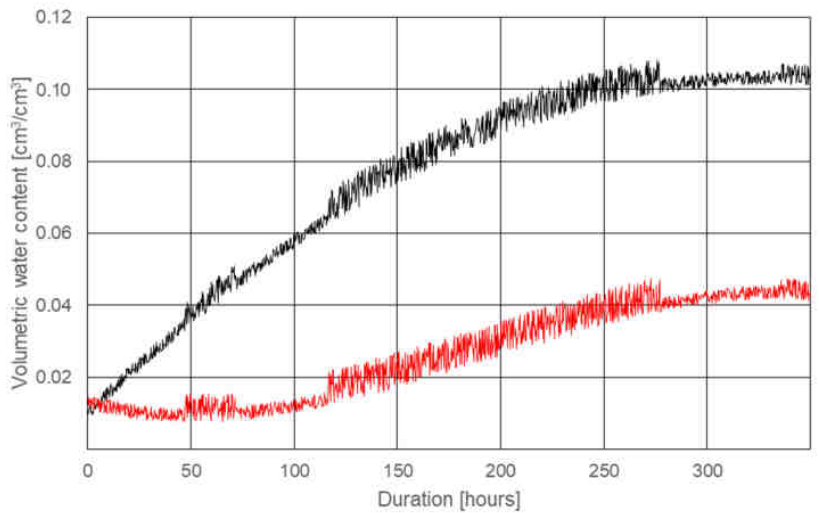

b)

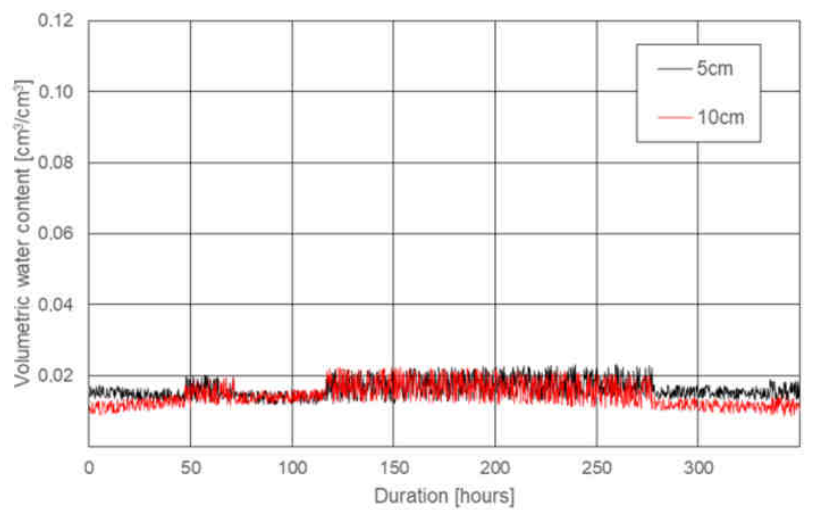

Fig. 4. Capillary rise phenomenon determined within the described research: a) aggregate-concrete without sludge supplementation, b) aggregate concrete with aggregates from sewage sludge 
Calibration formula and basic statistical parameters of the applied model of regression

\begin{tabular}{|c|c|c|c|c|c|}
\hline Model of regression & $\boldsymbol{R}^{2}$ & $\boldsymbol{R S E}$ & $\boldsymbol{R M S E}$ & $\boldsymbol{U}_{\max }$ & $\boldsymbol{F}$ Statistics \\
\hline$\theta=-0.0044+0.0587 \varepsilon_{\text {eff }}-0.0948 \varepsilon_{\text {eff }}^{2}$ & 0.98 & $\begin{array}{c}0.0007 \\
(d f=3)\end{array}$ & 0.005 & 0.014 & $\begin{array}{c}71.53\left(^{* *}\right) \\
(d f=2 ; 3)\end{array}$ \\
\hline
\end{tabular}

$R^{2}$ - coefficient of determination, $R S E$ - relative standard error, $R M S E$ - root mean square error, $U_{\max }$ - maximal value of standard uncertainty, $d f$ - degrees of freedom, ${ }^{* *}$ - level of significance

The results of capillary rise phenomenon determined using the TDR equipment (surface probe + regression formula) are presented in Figure 4. The conducted research confirmed the decreased capillary parameters of the examined concretes.

The readouts of thermal conductivity coefficient in dry for both types of concrete are presented in Table 5.

Thermal conductivity coefficient of examined concretes

Table 5

\begin{tabular}{|c|c|}
\hline \multirow{2}{*}{ Type of concrete } & \multicolumn{1}{|c|}{$\boldsymbol{\lambda} /(\mathbf{m} \cdot \mathbf{K})]$} \\
\cline { 2 - 2 } & 0.67 \\
\hline Without sludge additives & 0.52 \\
\hline $\begin{array}{c}\text { With aggregates from } \\
\text { sewage sludge }\end{array}$ & \\
\hline
\end{tabular}

\section{Discussion}

This sub-chapter contains the analysis of physical-chemical parameters of the aggregate-concretes obtained from Light Aggregates Company "Keramzyt" in Mszczonow, Poland and partially manufactured from sewage sludge.

According to the measurements and calculations described above, the mass of the concrete unit (apparent density) equals $1446 \mathrm{~kg} / \mathrm{m}^{3}$ for aggregate-concrete without sludge and $1347 \mathrm{~kg} / \mathrm{m}^{3}$ for aggregate with sewage supplementation. These values are standard for light concretes, with the apparent density not exceeding $800-2000 \mathrm{~kg} / \mathrm{m}^{3}$. The real density, 2381 for non-sludge mixture and $2453 \mathrm{~kg} / \mathrm{m}^{3}$ for mixture with sludge. Porosity of both concretes is high and reaches 45.6 for the one with sewage sludge and is $15.44 \%$ greater from light concrete with aggregates from Mszczonow, without sludge supplementation.

The research of the capillary uptake phenomenon monitored with the modified TDR instrumentations confirmed the decreased capillary parameters of the examined materials. In the case of the sample without sludge supplementation, the progress of the process was slow. The first moisture increase readouts were observed by the probe placed at level of $5 \mathrm{~cm}$ above water table. It was noticed shortly after beginning of the experiment. Within the next 250 hours, the progress of the phenomenon was significant enough to reach the level of $10 \%$ vol. Maximum water content read by the bottom probe was reached after the period of about 300 hours and it was about $11 \%$ vol. It should be mentioned that this value was equal to the maximum material absorptivity $\left(7 \%_{\text {mass }}=11 \%_{\mathrm{vol}}\right.$ for this material). In the case of the second probe, installed at the level of $10 \mathrm{~cm}$ above the water table, moisture increase was significantly slower. The first water appearance was read after about 120 hours since the experiment was started. Maximum moisture read by the reflectometer was about $4 \%_{\mathrm{vol}}$.

In the case of the second sample, i.e. with aggregates from sewage sludge, almost no significant water increase was observed. The readouts of two probes were unstable and 
varied between 0 and $2 \%_{\text {vol }}$. This ought to be considered as standard uncertainty of the TDR method, which according to many literature sources is about $2 \%[40,41]$.

Thermal conductivity coefficient $\lambda$ in a dry state of the lightweight aggregate-concrete with aggregates without additives is about $10 \%$ higher compared to the concrete with sewage sludge. This confirms superior thermal properties of the lightweight aggregate-concrete with sewage sludge. The values of thermal conductivity coefficient characterizing both materials are significantly lower comparing to standard concretes $(1.3-2.0 \mathrm{~W} /(\mathrm{m} \cdot \mathrm{K}))$; on the other hand, they are worse comparing to aerated concretes $(0.08-0.2 \mathrm{~W} /(\mathrm{m} \cdot \mathrm{K}))$ or composites of biological origin $(0.1-0.15 \mathrm{~W} /(\mathrm{m} \cdot \mathrm{K}))$ [43].

The samples of aggregate-concrete prepared from the aggregates modified with sewage-sludge as well as the aggregates from Mszczonow were subjected to the research, performed by means of a Scanning Electron Microscope (SEM). It revealed the morphology as well as the form of the crystalline phases which were formed in the lightweight concrete. The hardened cement mortar, prepared from Portland cement, is made up of hydrated calcium silicates (C-S-H phases) in $70 \%$, whereas the remaining $30 \%$ mostly includes calcium hydroxide as well as calcium aluminate-ferrate and aluminate hydration products. Good adhesion characterizing the contact points between cement mortar and aggregate aggregates was confirmed by the microscopic research. Additionally, as shown in Figure 5, their surface was free of cracks, scratches or empty gaps.

a)

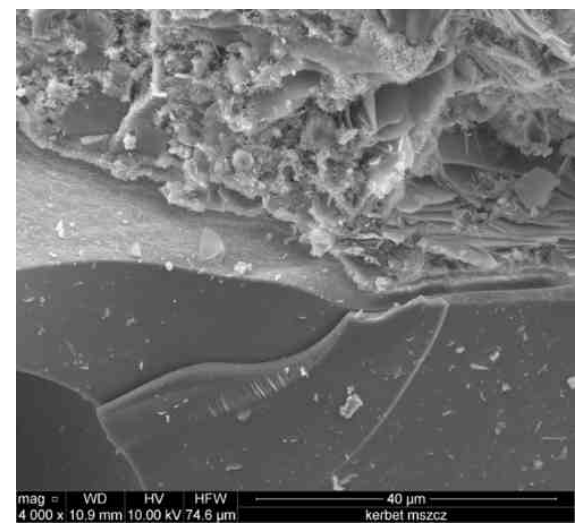

b)

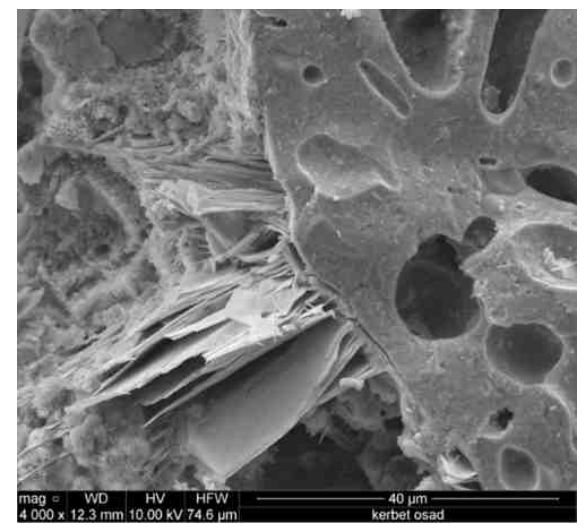

Fig. 5. SEM photographs of the contact point between: a) lightweight aggregates (Mszczonow) and the cement mortar; and b) lightweight aggregates with sewage sludge supplementation and the cement mortar

The cement mortar comprises two distinct mineral phases. The morphology of the first, formed by C-S-H phase is similar to the 3D honeycomb structure (see Fig. 6) and amorphous C-S-H phase agglomerates which are tightly compacted. Concretions formed by massive, hexagonal, tabular crystals of portlandite constitute other components. Their size $(10 \mu \mathrm{m})$ is greater than the one characterizing $\mathrm{C}-\mathrm{S}-\mathrm{H}$ phase. 
a)

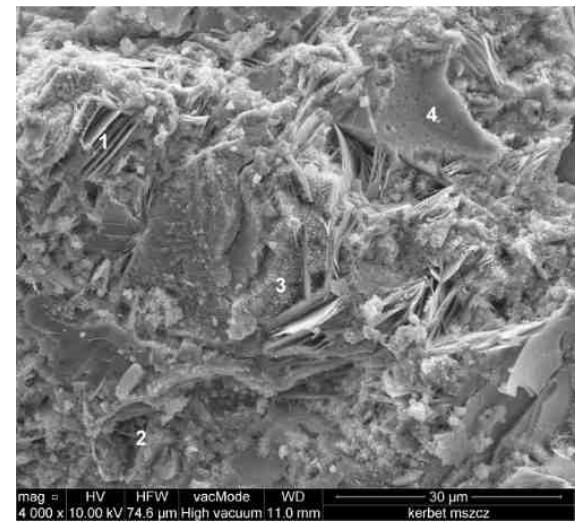

b)

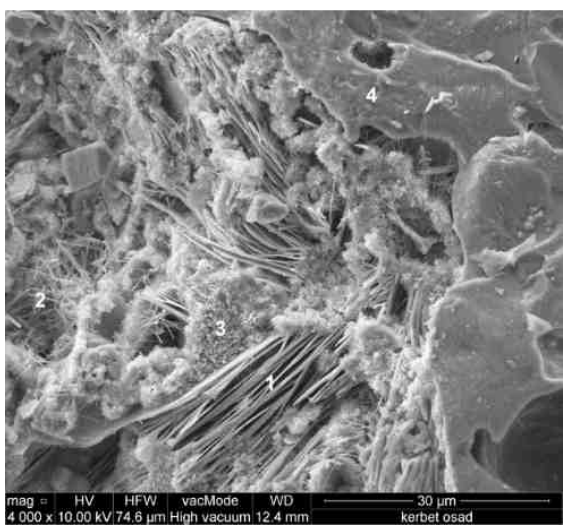

Fig. 6. Lightweight aggregate concrete: a) with aggregates from Mszczonow; and b) with aggregates of sewage sludge additives - mineral phases in cement mortar; 1 - portlandite; 2 - etryngite, 3 - C-S-H phase, 3D honeycomb structure; 4 - C-S-H phase, solid type

\section{Conclusions}

According to the research on the lightweight aggregate concrete with traditional aggregates (from Light Aggregates Company "Keramzyt" in Mszczonow, Poland) and aggregates with sewage supplementation the, following conclusions may be formulated:

- Light concretes, characterized by the apparent densities ranging from 800 to $2000 \mathrm{~kg} / \mathrm{m}^{3}$ can be obtained by using aggregate-concrete modified with sewage sludge. Apparent density of the lightweight concrete manufactured basing on sewage sludge aggregates equals $1347 \mathrm{~kg} / \mathrm{m}^{3}$.

- Sewage sludge addition reduced the apparent density of the material by $6.85 \%$ and simultaneously raised the total porosity by $15.44 \%$, in comparison to the commercially available aggregate concrete.

- Both aggregate-concretes are characterized by the absorptivity in the range of 4-7\%, particularly resulting from supplementing the concrete with a hydrophobic agent. The aggregate with sewage sludge addition absorbed a greater amount of preparation, due to a higher porosity and absorptivity, resulting in $43 \%$ lower total absorptivity of the lightweight concrete.

- Time Domain Reflectometry readouts proven than the capillary rise process was completely inhibited.

- Thermal conductivity coefficient was reduced by approximately 7-10\% owing to the sewage sludge addition to aggregate concretes.

- $\quad$ SEM analysis confirmed good adhesion of the contact points between cement mortar and aggregate aggregates.

- The research indicated that sewage sludge may be successfully added to lightweight concrete. However, strength examinations of the obtained concrete must be carried out in order to conduct a full verification of this finding. 


\section{Acknowledgements}

Authors greatly acknowledge the financial support received from Polish Ministry of Science and Higher Education and Czech Ministry of Education, Youth and Sport of the Czech Republic under project No 7 AMB16PL044, No 8JPL19027, Czech Science Foundation under project No. 17-02815S, and NAWA PPN/BIL/2018/1/00045/00001, together with the statutory research number S-70/WIŚ/2018.

\section{References}

[1] Życzyńska A. Eksploat Niezawodn. 2013; 15(4):458-462. http://ein.org.pl/sites/default/files/2013-04-25.pdf.

[2] Ickiewicz I. Ecol Chem Eng S. 2013;20(4):805-816. DOI: 10.2478/eces-2013-0056.

[3] Directive 2006/32/EC of the European Parliament and of the Council of 5 April 2006 on energy end-use efficiency and energy services and repealing Council Directive 93/76/EEC.2006. https://eur-lex.europa.eu/LexUriServ/LexUriServ.do?uri=OJ:L:2006:114:0064:0085:EN:PDF.

[4] Central Statistical Office. Energy Efficiency in the Years 1997-2007. Warszawa, Poland: Central Statistical Office; 2009. https://stat.gov.pl/cps/rde/xbcr/gus/ee_energy_efficiency_in_Poland_1997-2007.pdf.

[5] Dylewski R, Adamczyk J. Build Environ. 2011;46:2615-2623. DOI: 10.1016/j.buildenv.2011.06.023

[6] Aditya L, Mahlia TMI, Rismanchi B, Ng HM, Hasan MH, Metselaar HSC, et al. Renew Sust Energy Rev. 2017;73:1352-1365. DOI: 10.1016/j.rser.2017.02.034.

[7] Záleská M, Pavlíková M, Pokorný J, Jankovský O, Pavlík Z, Černý R. Constr Build Mater. 2018; 180:1-11. DOI: 10.1016/j.conbuildmat.2018.05.250.

[8] Cetiner I, Shea AD. Energy Buildings. 2018; 168:374-384. DOI:10.1016/j.enbuild.2018.03.019.

[9] Miskinis K, Dikavicius V, Buska A, Banionis K. Appl Acoust. 2018;137:62-68. DOI: 10.1016/j.apacoust.2018.03.001.

[10] Yang L, Xia J, Shen Q. Util Policy. 2016;41:57-66. DOI: 10.1016/j.jup.2016.06.001.

[11] D'Agostino D, Cuniberti B, Bertoldi P. Energy Buildings. 2017;153:72-86. DOI: 10.1016/j.enbuild.2017.07.062.

[12] Wang C, Shi J, Chen Z, Zha X. Procedia Eng. 2017;205:3056-3060. DOI: 10.1016/j.proeng.2017.10.273.

[13] Chenari B, Carrilho JD, Gameiro da Silva M. Renew Sust Energy Rev. 2016;59:1426-1447. DOI: 10.1016/j.rser.2016.01.074.

[14] Fernández-Agüera J, Domínguez-Amarillo S, Alonso C, Martín-Consuegra F. Energy Buildings. 2019;199:102-114. DOI: 10.1016/j.enbuild.2019.06.052.

[15] Suchorab Z, Barnat-Hunek D, Sobczuk H.. Ecol Chem Eng S. 2011;18(1):111-120. https://drive.google.com/file/d/15RNIEZxhsjc4AD2Pm3w90ZtXim0wJJba/view.

[16] Nguyen LH, Beaucour AL, Ortola S, Noumowé A. Constr Build Mater. 2017;151:720-731. DOI: 10.1016/j.conbuildmat.2017.06.087.

[17] Huo X, Sun Y, Hou J, Wang P, Kong X, Zhang Q, et al. Build Environ. 2019;106283. DOI: 10.1016/j.buildenv.2019.106283.

[18] Takada S. Energy Procedia. 2015;78:2772-2777. DOI: 10.1016/j.egypro.2015.11.623.

[19] Ababutain IM. Am J Appl Sci. 2013;10:159-163. DOI: 10.3844/ajassp.2013.159.163.

[20] Johansson P, Bok G, Ekstrand-Tobin A. Build Environ. 2013;65:178-184. DOI: 10.1016/j.buildenv.2013.04.004.

[21] Thelandersson S, Isaksson T. Build Environ. 2013;65:18-25. DOI: 10.1016/j.buildenv.2013.03.016.

[22] Franus M, Barnat-Hunek D, Wdowin M. Environ Monit Assess. 2016;188:10. DOI: 10.1007/s10661-015-5010-8.

[23] Gonzalez-Corrochano B, Alonso-Azcarate J, Rodas M. J Environ Manage. 2009;90:2801-2812. DOI: 10.1016/j.jenvman.2009.03.009.

[24] Lee TC, Lin KL, Su XW, Lin KK. Constr Build Mater. 2012;30:243-251. DOI: 10.1016/j.conbuildmat.2011.11.019.

[25] Huang SC, Chang FC, Lo SL, Lee MY, Wang CF, Lin JD. J Hazard Mater. 2007;144:52-58. DOI: 10.1016/j.jhazmat.2006.09.094.

[26] Cheeseman CR, Makinde A, Bethanis S. Res Conserv Recycl. 2005;43:147-162. DOI: 10.1016/j.resconrec.2004.05.004.

[27] Montusiewicz A, Lebiocka M, Pawłowska M. Arch Environ Prot. 2008;34:49-61. http://ipis.pan.pl/dokumenty/archives/roczniki/2008/3-7.pdf. 
[28] Commission of European Communities Council Directive 91/156/EEC on waste. https://eur-lex.europa.eu/legal-content/EN/TXT/PDF/?uri=CELEX:31991L0156\&from=LV.

[29] Commission of European Communities Council Directive 91/271/EEC of March 1991 concerning urban waste-water treatment (amended by the 98/15 EC of 27 February 1998). https://eur-lex.europa.eu/ legal-content/EN/TXT/?uri=LEGISSUM\%3A128008.

[30] Commission of European Communities Council Directive 99/31/EC of 26 April 1999 on the landfill waste. https://eur-lex.europa.eu/legal-content/EN/TXT/?uri=LEGISSUM\%3A121208.

[31] Commission of European Communities Council Directive 86/278/EEC of 4 July 1986 on the protection of the environment and in particular of the soil, when sewage sludge is used in agriculture. https://eur-lex.europa.eu/legal-content/EN/TXT/PDF/?uri=CELEX:31986L0278\&from=EN.

[32] Jordán MM, Almendro-Candel MB, Romero M, Ma Rincón J. Appl Clay Sci. 2005;30:219-224. DOI: 10.1016/j.clay.2005.05.001.

[33] Kaszyńska M. Lekkie betony samozagęszczalne do konstrukcji mostowych (Self-compacting lightweight concretes for bridge constructions). Nowoczesne Budownictwo Inżynieryjne. 2009;2(23):68-72. http://www.nbi.com.pl/assets/NBI-pdf/2009/2_23_2009/pdf/19_lekkie_betony.pdf.

[34] Chiang KY, Chou PH, Hua CR, Chien KL, Cheeseman CR. J Hazard Mater. 2009;171:76-82. DOI: 10.1016/j.jhazmat.2009.05.144.

[35] Jo BW, Park SK, Park JB. Cement Concr Comp. 2007;29:128-135. DOI: 10.1016/j.cemconcomp.2006.09.004.

[36] Frattolillo A, Giovinco G, Mascolo MC, Vitale A. Exp Therm Fluid Sci. 2005;30:27-35. DOI: 10.1016/j.expthermflusci.2004.12.006.

[37] Demirbo R, Gül R. CemConc Res. 2003;33:723-727. DOI: 10.1016/S0008-8846(02)01032-3.

[38] Polish Standard PN-EN 206-1:2003/A2:2006P. Concrete. Specification, performance, production and conformity. Warszawa: Polish Committee for Standardization; 2006. http://sklep.pkn.pl/ pn-en-206-1-2003-a2-2006p.html.

[39] Polish Standard PN-EN 1936:2010. Natural stone test methods. Determination of real density and apparent density, and of total and open porosity. Warszawa, Poland: Polish Committee for Standardization; 2010. http://sklep.pkn.pl/pn-en-1936-2010p.html.

[40] Vidana Gamage DN, Biswas A, Strachan IB. Soil Till Res. 2019;193:50-58. DOI: 10.1016/j.still.2019.05.012.

[41] Černý R. Measurement. 2009;42:329-336. DOI: 10.1016/j.measurement.2008.08.011.

[42] Skierucha W, Wilczek A, Alokhina O. Sens Actuator A-Phys. 2008;147:544-552. DOI: 10.1016/j.sna.2008.06.015

[43] Brzyski P, Barnat-Hunek D, Suchorab Z, Łagód G. Materials. 2017;10(5). DOI: 10.3390/ma10050510. 